\title{
The Effect of Dietary Nitrate Supplementation on Isokinetic Torque in Adults: A Systematic Review and Meta-Analysis
}

\author{
Ángel Lago-Rodríguez ${ }^{1}{ }^{(0)}$, Raúl Domínguez ${ }^{2, *}$ (D) Juan José Ramos-Álvarez ${ }^{3}{ }^{(0)}$, \\ Francisco Miguel Tobal ${ }^{3}$, Pablo Jodra ${ }^{4}\left(\mathbb{D}\right.$, Rachel Tan $^{5}{ }^{(D)}$ and Stephen J. Bailey ${ }^{6}$ \\ 1 Faculty of Health Sciences, Universidad Isabel I, 09003 Burgos, Spain; angellagorodriguez@gmail.com \\ 2 Studies Research Group in Neuromuscular Responses (GEPREN), University of Lavras, \\ 37200-000 Lavras, Brazil \\ 3 Faculty of Medicine, School of Medicine of Physical Education and Sport, Complutense University, \\ 28040 Madrid, Spain; jjramosa@ucm.es (J.J.R.-Á.); miguelto@ucm.es (F.M.T.) \\ 4 Faculty of Education Sciences, University of Alcalá, 19001 Guadalajara, Spain; pablo.jodraj@uah.es \\ 5 Faculty of Sports Medicine, Natural Sciences Division, Pepperdine University, Malibu, CA 90263, USA; \\ rachel.tan@pepperdine.edu \\ 6 School of Sport, Exercise and Health Sciences, Loughborough University, Loughborough LE11 3TU, UK; \\ s.bailey2@lboro.ac.uk \\ * Correspondence: raul_dominguez_herrera@hotmail.com; Tel.: +34-695182853
}

Received: 26 August 2020; Accepted: 29 September 2020; Published: 2 October 2020

check for updates

\begin{abstract}
Dietary nitrate $\left(\mathrm{NO}_{3}{ }^{-}\right)$supplementation, which can enhance performance in exercise settings involving repeated high-intensity efforts, has been linked to improved skeletal muscle contractile function. Although muscular strength is an important component of explosive movements and sport-specific skills, few studies have quantified indices of muscular strength following $\mathrm{NO}_{3}{ }^{-}$ supplementation, particularly isokinetic assessments at different angular velocities. We performed a systematic review and meta-analysis to determine whether dietary $\mathrm{NO}_{3}{ }^{-}$supplementation improves peak torque, as assessed by the gold standard method of isokinetic dynamometry, and if this effect was linked to the angular velocity imposed during the assessment. Dialnet, Directory of Open Access Journals, MEDLINE, PubMed, SciELO, Scopus, and SPORTDiscus were searched for articles using the following search strategy: (nitrate OR beet*) AND (supplement* OR nutr* OR diet*) AND (isokinetic OR strength OR "resistance exercise" OR "resistance training" OR "muscular power"). The meta-analysis of data from 5 studies with 60 participants revealed an overall effect size of -0.01 for the effect of nitrate supplementation on isokinetic peak torque, whereas trivial effect sizes ranging from -0.11 to 0.16 were observed for independent velocity-specific $\left(90^{\circ} / \mathrm{s}, 180^{\circ} / \mathrm{s}, 270^{\circ} / \mathrm{s}\right.$, and $\left.360^{\circ} / \mathrm{s}\right)$ isokinetic peak torque. Four of the five studies indicated that dietary $\mathrm{NO}_{3}{ }^{-}$supplementation is not likely to influence voluntary knee extensor isokinetic torque across a variety of angular velocities. These results suggest that $\mathrm{NO}_{3}{ }^{-}$supplementation does not influence isokinetic peak torque, but further work is required to elucidate the potential of $\mathrm{NO}_{3}{ }^{-}$supplementation to influence other indices of muscular strength, given the dearth of experimental evidence on this topic.
\end{abstract}

Keywords: beetroot; ergogenic aid; exercise performance; strength; muscle

\section{Introduction}

Performance outcome in a variety of sports is determined by the ability to perform a range of rapid, dynamic, and explosive movements such as sprinting, changing direction, jumping, and exhibiting sport-specific skills (e.g., kicking, throwing, or hitting a ball). Indeed, the ability to produce force and 
power is considered among the most important factors for optimizing overall athletic performance [1,2]. It is important to note that there are a variety of methods to quantify force production (i.e., strength), such as isokinetic dynamometry, isometric assessments, resistance exercise protocols (e.g., one-repetition maximum (1RM), 3-10RM), and field tests (e.g., hand-grip and hand-held dynamometry, and body mass muscle testing such as vertical jump height) $[3,4]$. Each method provides different parameters of strength and has specific inherent weaknesses [5], such that strength assessments may not be equivalent between methods [4]. Although isokinetic strength measures have limited translation to sport-specific tasks, since these are rarely completed at an isokinetic pace [6], isokinetic assessments have several important advantages. These conducting assessments against a maximal resistance throughout the complete range of motion of a joint at different movement velocities [7], and the possibility of measuring torque [8]. In addition, isokinetic strength assessment is a highly reliable method for the measurement of force production $[7,9,10]$. Consequently, isokinetic dynamometry has been proposed as a gold standard method of strength assessment [11-14].

Dietary supplementation strategies (e.g., beta-alanine, sodium bicarbonate, and creatine) are often implemented in an attempt to enhance performance during single or intermittent maximal contractions; however, there are few supplements evidenced to be ergogenic in single intermittent maximal contractions [15]. One such supplement that may improve single maximal voluntary contractile function is inorganic nitrate $\left(\mathrm{NO}_{3}{ }^{-}\right)$, which is typically administered as $\mathrm{NO}_{3}{ }^{-}$-rich beetroot juice (BR) [16]. Following ingestion, $\mathrm{NO}_{3}{ }^{-}$is metabolized via the sequential reduction of $\mathrm{NO}_{3}{ }^{-}$to nitrite $\left(\mathrm{NO}_{2}{ }^{-}\right)$and subsequently to nitric oxide (NO) [17], which plays a crucial role in skeletal muscle function [18]. The elevation in NO bioavailability following BR ingestion is thought to underpin the enhanced type II muscle fiber contractile function [18], lowered ATP cost of force production [5], and improved blood flow to the skeletal muscle $[19,20]$. More specifically, $\mathrm{NO}_{3}{ }^{-}$-induced enhancements to skeletal muscle contractile function may be due to improved calcium $\left(\mathrm{Ca}^{2+}\right)$ handling $[21,22]$.

The effect of $\mathrm{NO}_{3}{ }^{-}$supplementation on involuntary electrically evoked contractions is equivocal. $\mathrm{NO}_{3}{ }^{-}$supplementation has been reported to increase force production at low stimulation frequencies in some $(\leq 20 \mathrm{~Hz})[22-24]$, but not all studies $[25,26]$. Although dietary $\mathrm{NO}_{3}{ }^{-}$supplementation has been reported to improve maximal voluntary contractile force during a mid-thigh pull [27], most studies have not observed an increase in maximal voluntary isometric contractile force when contracting the knee extensors $[19,22,23,25,26,28,29]$. Acute $\mathrm{NO}_{3}{ }^{-}$ingestion has been reported to enhance peak torque during isokinetic dynamometry at high but not low angular velocities [30-32]. Type II muscle fibers are more likely to be recruited at high angular velocities $[33,34]$ and $\mathrm{NO}_{3}{ }^{-}$appears to be more effective at improving contractile function in type II muscle fibers [21]. This might account for the potential velocity-specific effects of $\mathrm{NO}_{3}{ }^{-}$supplementation. Further evidence to support a potential velocity-specific effect of $\mathrm{NO}_{3}{ }^{-}$supplementation is evidenced by increased peak power output [35-37] during a $30 \mathrm{~s}$ Wingate test performed using an inertial cycle ergometer, which results in faster pedaling cadence compared with an isokinetic cycle ergometer [38], and improved time to exhaustion when cycling at a high $(115 \mathrm{rpm})$ but not a low $(35 \mathrm{rpm})$ pedal cadence, after $\mathrm{NO}_{3}{ }^{-}$ supplementation [39]. However, there is currently a paucity of published reports examining the effect of $\mathrm{NO}_{3}{ }^{-}$supplementation on torque at different angular velocities, and studies that have addressed this have yielded disparate findings $[30,40]$. Determining the potential of $\mathrm{NO}_{3}{ }^{-}$supplementation to elicit velocity-specific effects on skeletal muscle contractile function is important to help inform exercise settings in which $\mathrm{NO}_{3}{ }^{-}$supplementation is more and less likely to be ergogenic. Since isokinetic strength assessment is a reliable method for analyzing force production [10] at different movement velocities [7], it was selected as the experimental approach to assess the potential of $\mathrm{NO}_{3}{ }^{-}$ supplementation to improve skeletal muscle contractile function.

The aim of the present study was threefold: (i) to perform a systematic review of the studies that have investigated the effect of $\mathrm{NO}_{3}{ }^{-}$supplementation on isokinetic torque production, (ii) to conduct a meta-analysis of reported findings, and (iii) to explore whether there is a velocity-specific 
effect of $\mathrm{NO}_{3}{ }^{-}$supplementation on isokinetic torque production. It was hypothesized that $\mathrm{NO}_{3}{ }^{-}$ supplementation would improve isokinetic torque at high but not low angular velocities.

\section{Methods}

The present systematic review and meta-analysis followed the Preferred Reporting Items for Systematic Reviews and Meta-Analysis (PRISMA) guidelines [41] and the PICOS (population, intervention, comparison, outcome, setting) criteria [42] and was conducted using Dialnet, Directory of Open Access Journals, MEDLINE, PubMed, SciELO, Scopus, and SPORTDiscus databases, including all results published before April 2020. The search strategy terms used were as follows: (nitrate OR beet $^{*}$ ) AND (supplement* OR nutr* OR diet*) AND (isokinetic OR strength OR "resistance exercise" OR "resistance training" OR "muscular power"). To our knowledge, this is the first systematic review on this topic, and therefore the search did not include limitations of publication date or language. The original search yielded a total of 546 results. After the elimination of duplicates and screening of inclusion criteria, a total of 70 full-text articles were identified and reviewed by three authors (J.J.R.-Á., F.M.T., P.J.). A quality assessment was performed by two authors (J.J.R.-Á., F.M.T.) according to the PEDro scale [43]. A total of five articles met the eligibility criteria for the present systematic review and meta-analysis (Figure 1).

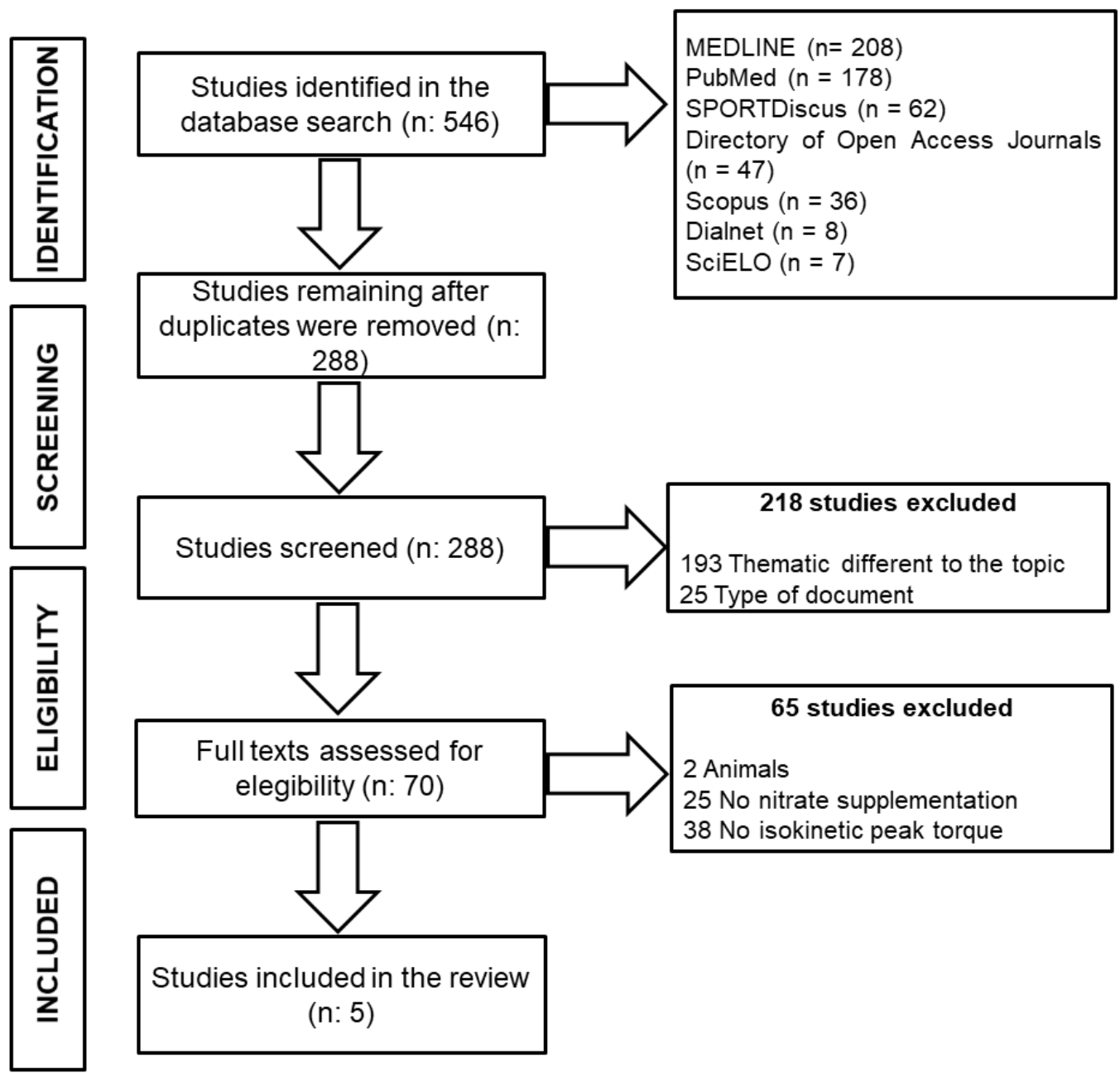

Figure 1. Preferred Reporting Items for Systematic Reviews and Meta-Analysis (PRISMA) flowchart. 
Based on the PICOS criteria, the following inclusion criteria were applied:

- $\quad$ Studies that were published as a full article and performed in adults (age 18-80 years);

- $\quad$ Studies that included a $\mathrm{NO}_{3}{ }^{-}$and placebo intervention;

- Studies that assessed and reported isokinetic torque measures;

- Studies that employed a randomized double-blind experimental design.

Since this systematic review and meta-analysis was focused on isokinetic peak torque, we asked corresponding authors to provide maximum isokinetic torque data when they were not directly reported in the original article.

Meta-analytic statistical analysis was performed using Review Manager (RevMan) version 5.3 (Copenhagen: The Nordic Cochrane Centre, The Cochrane Collaboration, 2014). A fixed-effects model was applied and performed using mean and standard deviation of peak torque and the number of participants to quantify the standardized mean differences (SMDs) between $\mathrm{NO}_{3}{ }^{-}$and placebo interventions, calculated as Hedges' g [44]. The SMDs for each study were weighted as the reciprocal of their variance in order to calculate an overall effect and 95\% confidence interval (CI), both for the overall movement velocities reported in the reviewed studies (i.e., overall analysis) and for each movement velocity reported at least in two studies (i.e., subgroup analysis). Effect sizes were defined as trivial $(<0.2)$, small $(<0.5)$, moderate $(<0.8)$, and large $(>0.8)[45] . I^{2}$ values were calculated for the percentage of total variation among studies [46]. $I^{2}$ values were defined as small (25-50\%), medium (50-75\%), and large (>75\%) [47].

The five studies included in the systematic review and meta-analysis comprised a total of 60 participants (38 males and 22 females, age $47 \pm 18$ years, BMI $26 \pm 2 \mathrm{~kg} \cdot \mathrm{m}^{-2}$ ). All of the included studies provided acute administration of commercially available concentrated $\mathrm{NO}_{3}{ }^{-}$-rich beetroot juice (BR; Beet It Sport, James White Drinks, Ipswich, UK) $120 \mathrm{~min}$ prior to exercise $(2 \times 70 \mathrm{~mL} ; 11.2-13.4 \mathrm{mmol}$ of $\left.\mathrm{NO}_{3}{ }^{-}\right)$[30-32,48] or $180 \mathrm{~min}$ prior to exercise $\left(1 \times 70 \mathrm{~mL} ; 6.4 \mathrm{mmol}^{\circ} \mathrm{NO}_{3}^{-}\right)$[40].

\section{Results}

A summary of the methodologies and results of the studies included in this systematic review is provided in Table 1. Isokinetic dynamometry was used in all studies to assess voluntary peak torque production at various angular velocities ranging from stationary $\left(0^{\circ} / \mathrm{s}\right)$ to fast movement $\left(360^{\circ} / \mathrm{s}\right)$. In one study, knee extension and flexion were performed at $60^{\circ} / \mathrm{s}$ and $240 \% \mathrm{~s}$ [40], respectively, while in the remaining studies, knee extensions were perfomed at $0^{\circ} / \mathrm{s}, 90^{\circ} / \mathrm{s}, 180^{\circ} / \mathrm{s}, 270^{\circ} / \mathrm{s}$, and $360^{\circ} / \mathrm{s}[30-32,48]$.

There was an improvement in knee extension peak torque at a high angular velocity of $360^{\circ} / \mathrm{s}$ following $\mathrm{NO}_{3}{ }^{-}$supplementation [31], but not during slower movement angular velocities of $60^{\circ} / \mathrm{s} \mathrm{[40],}$ $90^{\circ} / \mathrm{s}[30,31,48], 180^{\circ} / \mathrm{s}$ [30-32,48], $240^{\circ} / \mathrm{s}$ [40], or $270^{\circ} / \mathrm{s}$ [30-32,48] (Table 1). There was no effect of $\mathrm{NO}_{3}{ }^{-}$supplementation on knee flexion peak torque at slow- or fast-movement angular velocities of $60 \%$ s or $240^{\circ} / \mathrm{s}$ respectively [40]. 
Table 1. Studies assessing the effects of dietary $\mathrm{NO}_{3}{ }^{-}$supplementation on isokinetic peak torque production in humans.

\begin{tabular}{|c|c|c|c|c|}
\hline Reference & Subjects & Supplementation & Exercise Protocol & Findings (BR vs. PL) \\
\hline Coggan et al. [30] & $\begin{array}{c}7 \mathrm{M} / 5 \mathrm{~F} \text { healthy } \\
\text { adults }\end{array}$ & $\begin{array}{c}120 \mathrm{~min} \text { prior to } \\
\text { exercise ingestion } \\
\text { of } 2 \times 70 \mathrm{~mL} \mathrm{BR} \\
\text { shots }(\sim 11.2 \mathrm{mmol} \\
\left.\quad \mathrm{NO}_{3}^{-}\right)\end{array}$ & $\begin{array}{c}\text { Isokinetic knee } \\
\text { extension peak } \\
\text { torque at: } 90^{\circ} / \mathrm{s}, \\
180^{\circ} / \mathrm{s}, 270^{\circ} / \mathrm{s} \text {, and } \\
360^{\circ} / \mathrm{s}\end{array}$ & $\begin{array}{c}-1.86 \% \text { at } 90^{\circ} / \mathrm{s} \\
-1.72 \% \text { at } 180^{\circ} / \mathrm{s} \\
+0 \% \text { at } 270^{\circ} / \mathrm{s} \\
+4.27 \% \text { at } 360^{\circ} / \mathrm{s}\end{array}$ \\
\hline Coggan et al. [31] & $\begin{array}{l}5 \mathrm{M} / 4 \mathrm{~F} \text { heart } \\
\text { failure patients }\end{array}$ & $\begin{array}{c}120 \mathrm{~min} \text { prior to } \\
\text { exercise ingestion } \\
\text { of } 2 \times 70 \mathrm{~mL} \mathrm{BR} \\
\text { shots }(\sim 11.2 \mathrm{mmol} \\
\left.\quad \mathrm{NO}_{3}^{-}\right)\end{array}$ & $\begin{array}{c}\text { Isokinetic knee } \\
\text { extension peak } \\
\text { torque at: } 90^{\circ} / \mathrm{s} \text {, } \\
180^{\circ} / \mathrm{s}, 270^{\circ} / \mathrm{s} \text {, and } \\
360^{\circ} / \mathrm{s}\end{array}$ & $\begin{array}{c}+1.47 \% \text { at } 90^{\circ} / \mathrm{s} \\
-3.81 \% \text { at } 180^{\circ} / \mathrm{s} \\
+9.41 \% \text { at } 270^{\circ} / \mathrm{s} \\
+10.94 \% \text { at } 360^{\circ} / \mathrm{s}^{*}\end{array}$ \\
\hline Coggan et al. [48] & $\begin{array}{c}13 \mathrm{M} / 7 \mathrm{~F} \text { healthy } \\
\text { young and older } \\
\text { adults }\end{array}$ & $\begin{array}{c}120 \mathrm{~min} \text { prior to } \\
\text { exercise ingestion } \\
\text { of } 2 \times 70 \mathrm{~mL} \mathrm{BR} \\
\text { shots }(\sim 12.3 \mathrm{mmol} \\
\left.\quad \mathrm{NO}_{3}^{-}\right)\end{array}$ & $\begin{array}{c}\text { Isokinetic knee } \\
\text { extension peak } \\
\text { torque at: } 90^{\circ} / \mathrm{s} \text {, } \\
180^{\circ} / \mathrm{s}, 270^{\circ} / \mathrm{s} \text {, and } \\
360^{\circ} / \mathrm{s}\end{array}$ & $\begin{array}{l}-3.11 \% \text { at } 90 \% \mathrm{~s} \\
-0.67 \% \text { at } 180 \% \mathrm{~s} \\
+0.8 \% \text { at } 270 \% \mathrm{~s} \\
+3.06 \% \text { at } 360^{\circ} / \mathrm{s}\end{array}$ \\
\hline Coggan et al. [32] & $\begin{array}{l}6 \mathrm{M} / 6 \mathrm{~F} \text { healthy } \\
\text { older adults }\end{array}$ & $\begin{array}{c}120 \mathrm{~min} \text { prior to } \\
\text { exercise ingestion } \\
\text { of } 2 \times 70 \mathrm{~mL} \mathrm{BR} \\
\text { shots }(\sim 13.4 \mathrm{mmol} \\
\left.\quad \mathrm{NO}_{3}^{-}\right)\end{array}$ & $\begin{array}{c}\text { Isokinetic knee } \\
\text { extension peak } \\
\text { torque relative to } \\
\text { body mass at: } 0^{\circ} / \mathrm{s}, \\
90^{\circ} / \mathrm{s}, 180^{\circ} / \mathrm{s}, 270^{\circ} / \mathrm{s} \\
\text { and } 360^{\circ} / \mathrm{s}\end{array}$ & $\begin{array}{c}-2.06 \text { at } 0 \% / \mathrm{s} \\
-2.82 \% \text { at } 90^{\circ} / \mathrm{s} \\
-2.94 \% \text { at } 180^{\circ} / \mathrm{s} \\
+0 \% \text { at } 270^{\circ} / \mathrm{s} \\
+8.33 \% \text { at } 360^{\circ} / \mathrm{s}\end{array}$ \\
\hline $\begin{array}{l}\text { Kokkinoplitis and } \\
\text { Chester [40] }\end{array}$ & $7 \mathrm{M}$ healthy adults & $\begin{array}{c}180 \mathrm{~min} \text { prior to } \\
\text { exercise ingestion } \\
\text { of } 1 \times 70 \mathrm{~mL} \mathrm{BR} \\
\text { shot }(\sim 6.4 \mathrm{mmol} \\
\left.\quad \mathrm{NO}_{3}^{-}\right)\end{array}$ & $\begin{array}{c}\text { Isokinetic knee } \\
\text { extension and } \\
\text { flexion peak torque } \\
\text { at: } 60^{\circ} / \mathrm{s} \text { and } 240^{\circ} / \mathrm{s}\end{array}$ & $\begin{array}{l}\text { Knee extension } \\
-3.47 \% \text { at } 60^{\circ} / \mathrm{s} \\
-5.56 \% \text { at } 240^{\circ} / \mathrm{s} \\
\text { Knee flexion } \\
-6.85 \% \text { at } 60^{\circ} / \mathrm{s} \\
-13.83 \% \text { at } 240^{\circ} / \mathrm{s}\end{array}$ \\
\hline
\end{tabular}

* = significant difference between BR and PL; BR: beetroot juice; PL: placebo juice; F: females; M: males; min: minutes; $\mathrm{NO}_{3}^{-}$: nitrate; s: seconds; ${ }^{\circ}$ : degrees.

There was a trivial effect size of -0.01 (CI: $-0.19,0.17 ; I^{2}: 0 \% ; p=1.00$; Figure 2 ) for the effect of $\mathrm{NO}_{3}{ }^{-}$supplementation on isokinetic torque production when data from all angular velocities were combined. Subgroup analysis on the effect of $\mathrm{NO}_{3}{ }^{-}$supplementation on knee extension isokinetic torque production at $60^{\circ} / \mathrm{s}, 90^{\circ} / \mathrm{s}, 180^{\circ} / \mathrm{s}, 240^{\circ} / \mathrm{s}, 270^{\circ} / \mathrm{s}$, and $360^{\circ} / \mathrm{s}$ revealed that there was a trivial effect size of 0.01 (CI: $-0.18,0.19 ; I^{2}: 0 \% ; p=1.00$ ). Independent analysis for each angular velocity revealed trivial effect sizes (ESs) for the effect of $\mathrm{NO}_{3}{ }^{-}$supplementation on knee extension isokinetic torque production at $90^{\circ} / \mathrm{s}$ (ES: $\left.-0.11, \mathrm{CI}:-0.49,0.27 ; I^{2}: 0 \% ; p=0.98\right), 180^{\circ} / \mathrm{s}$ (ES: $-0.02, \mathrm{CI}:-0.40,0.37$; $\left.I^{2}: 0 \% ; p=0.98\right), 270^{\circ} / \mathrm{s}\left(\mathrm{ES}: 0.08, \mathrm{CI}:-0.30,0.46 ; I^{2}: 0 \% ; p=0.92\right)$, and $360^{\circ} / \mathrm{s}\left(\mathrm{ES}: 0.16, \mathrm{CI}:-0.22,0.5 ; I^{2}\right.$ : $0 \% ; p=0.98)$. 


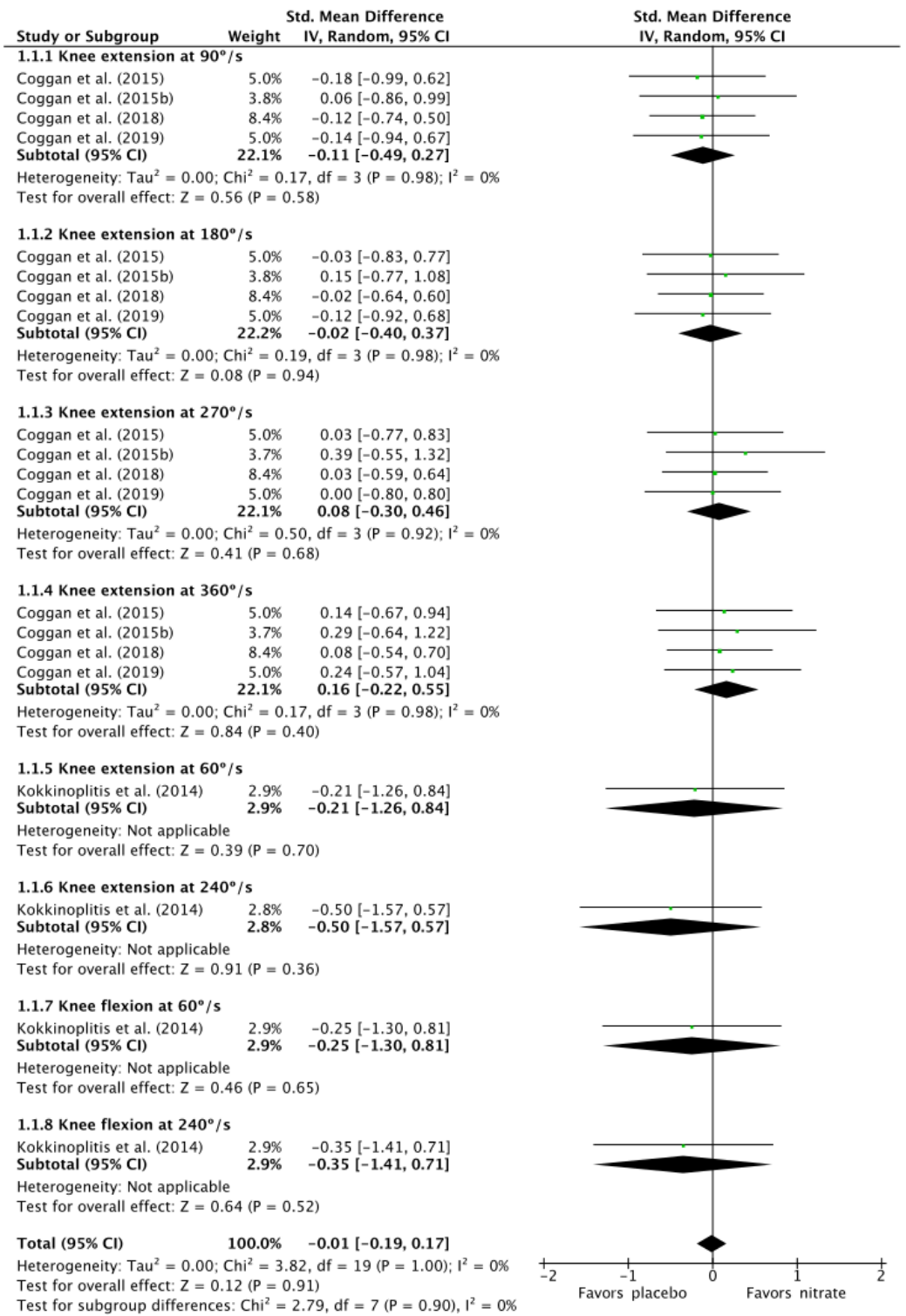

Figure 2. Forest plot comparing the effects of placebo and nitrate $\left(\mathrm{NO}_{3}{ }^{-}\right)$supplementation on isokinetic torque production. The size of the plotted squares reflects the statistical weight of the study. Horizontal lines denote the $95 \%$ confidence intervals.

\section{Discussion}

This is the first systematic review and meta-analysis to have investigated the potential influence of dietary $\mathrm{NO}_{3}{ }^{-}$supplementation on isokinetic torque at different angular velocities. The main finding was that acute dietary $\mathrm{NO}_{3}{ }^{-}$ingestion does not significantly alter isokinetic torque irrespective of the angular velocity imposed.

Of the five studies included in this review, only one study reported a significant $~ 11 \%$ improvement in knee extension peak torque at a high angular velocity of $360^{\circ} / \mathrm{s}$ [31], with two studies reporting a tendency for improved knee extension peak torque at $270 \% \mathrm{~s} \mathrm{(+9 \% )} \mathrm{[31]} \mathrm{and} 360^{\circ} / \mathrm{s}(+4 \%)$ [30] following acute $\mathrm{NO}_{3}{ }^{-}$ingestion. In contrast, the remainder of the studies reported that knee flexion [40] and knee extension peak torque at slow-to-moderate angular velocities were not influenced by $\mathrm{NO}_{3}{ }^{-}$ supplementation $[30-32,40,48]$. Therefore, the findings from the present meta-analysis suggests that acute dietary $\mathrm{NO}_{3}{ }^{-}$ingestion does not influence lower limb muscle isokinetic torque. 
It is recognized that the increase in plasma $\left[\mathrm{NO}_{2}{ }^{-}\right]$following $\mathrm{NO}_{3}{ }^{-}$supplementation is a correlate of improved performance $[48,49]$. Since plasma $\left[\mathrm{NO}_{2}{ }^{-}\right]$attains peak values $\sim 3 \mathrm{~h}$ post $\mathrm{NO}_{3}{ }^{-}$ ingestion [49-51], the lack of an effect of $\mathrm{NO}_{3}{ }^{-}$ingestion on peak torque across the range of angular velocities assessed in the current meta-analysis might be a result of the acute $\mathrm{NO}_{3}{ }^{-}$ingestion occurring $2 \mathrm{~h}$ prior to the peak torque assessments $[30-32,40,48]$ such that a suboptimal plasma $\left[\mathrm{NO}_{2}{ }^{-}\right]$was attained. It should also be highlighted that a limitation of some of the studies included in the current meta-analysis is that plasma $\left[\mathrm{NO}_{2}{ }^{-}\right]$was either not measured $[30,40]$, or was measured with an assay with insufficient sensitivity to detect an increase in plasma $\left[\mathrm{NO}_{2}{ }^{-}\right.$] post $\mathrm{NO}_{3}{ }^{-}$ingestion [31]. In addition, since all studies in the current meta-analysis assessed the effect of acute $\mathrm{NO}_{3}{ }^{-}$ingestion on peak torque at different angular velocities, and since there is evidence to suggest that chronic $\mathrm{NO}_{3}{ }^{-}$supplementation may be more ergogenic than acute $\mathrm{NO}_{3}{ }^{-}$ingestion (at least during endurance exercise $[52,53]$ ), chronic $\mathrm{NO}_{3}{ }^{-}$supplementation may have elicited enhanced isokinetic peak torque production. It is possible that chronic $\mathrm{NO}_{3}{ }^{-}$supplementation can elevate skeletal muscle tissue stores of $\mathrm{NO}_{3}{ }^{-}$and $\mathrm{NO}_{2}{ }^{-}$ compared to acute $\mathrm{NO}_{3}{ }^{-}$ingestion [54], which could facilitate improved skeletal muscle contractile performance. Moreover, chronic $\mathrm{NO}_{3}{ }^{-}$supplementation has been reported to increase the content of the calcium-handling proteins calsecuestrin (CASQ) and the dihydropyridine receptor (DHPR) in skeletal muscle, and evoked contractile force in mouse fast-twitch muscle, which supports the postulate that chronic $\mathrm{NO}_{3}{ }^{-}$supplementation could improve skeletal muscle contractile function [21]. Although an increase evoked for production was reported after chronic $\mathrm{NO}_{3}{ }^{-}$supplementation in humans, this was not accompanied by increases in skeletal muscle CASQ and DHPR content [22]. In addition, the lack of an effect as reported in the study by Kokkinoplitis and Chester [40] compared to the studies by Coggan and colleagues [30-32,48] could be a function of the lower $\mathrm{NO}_{3}{ }^{-}$dose $(6.4 \mathrm{mmol})$ administered in the former study. Indeed, it was reported that exercise performance dose-dependently increases after acute $\mathrm{NO}_{3}{ }^{-}$supplementation up to $8.4 \mathrm{mmol}$, with no additional performance benefits at $16.8 \mathrm{mmol}$ compared to $8.4 \mathrm{mmol}$, at least during endurance exercise [49]. Further research is required to address the effects of chronic $\mathrm{NO}_{3}{ }^{-}$supplementation on skeletal muscle contractile function and the potential mechanisms that could underpin an ergogenic effect.

It is becoming increasingly appreciated that the efficacy of $\mathrm{NO}_{3}{ }^{-}$supplementation is influenced by the population evaluated, which could be related to factors influencing NO bioavailability $[18,55]$. For example, basal NO synthesis is higher in individuals with a high cardiorespiratory fitness compared to that in senescent populations [56] and lower in individuals with a pathology [57,58]. There is also evidence that the increase in plasma $\left[\mathrm{NO}_{2}{ }^{-}\right]$(which is a sensitive $\mathrm{NO}$ biomarker [59]) after $\mathrm{NO}_{3}{ }^{-}$ supplementation is correlated to relative improvements to maximal knee extensor power $(R=0.60)$ [48]. Peak torque was enhanced to a greater extent in heart failure patients [31] compared to young and older healthy individuals $[30,32,40,48]$ after $\mathrm{NO}_{3}{ }^{-}$supplementation. This might be a function of impaired $\mathrm{NO}$ synthesis in heart failure patients, providing a greater scope for $\mathrm{NO}_{3}{ }^{-}$supplementation to increase NO synthesis and muscle contractile performance compared to healthy individuals with a higher residual NO synthesis and muscle function. Furthermore, sex differences may influence the efficacy of $\mathrm{NO}_{3}{ }^{-}$supplementation. Indeed, Coggan et al. [48] observed that females tended to have a greater magnitude of increase in maximal power after $\mathrm{NO}_{3}{ }^{-}$supplementation, which might be linked to the greater increase in plasma $\left[\mathrm{NO}_{2}{ }^{-}\right.$] after $\mathrm{NO}_{3}{ }^{-}$supplementation in females [50]. Since the efficacy of $\mathrm{NO}_{3}{ }^{-}$supplementation appears to be linked to $\mathrm{NO}$ synthesis, and since various subject population characteristics including health, age, and sex can modulate NO bioavailability, further research is required to aid understanding of the different settings in which $\mathrm{NO}_{3}{ }^{-}$supplementation might influence muscular strength.

It should be noted that there are a variety of methods to assess muscle contractile function; these methods range from isometric to the commonly implemented isotonic methods. In addition, there are methods that employ single-joint (isokinetic dynamometry) or multi-joint movements (1RM testing), which may have better reliability, sensitivity, and validity, while other methods may better translate to sport-specific performance [4]. Given the relative strengths and weaknesses of each approach, future 
studies should seek to implement multiple modes of assessment for strength in order to more clearly resolve the potential influence of $\mathrm{NO}_{3}{ }^{-}$supplementation on the muscle contractile function. It should also be acknowledged that although $\mathrm{NO}_{3}{ }^{-}$supplementation does not appear to influence isokinetic peak torque during independent angular velocity assessments, subsequent calculations of maximal power and velocity of contraction from peak torque values obtained across a series of independent angular velocity assessments were improved by $\mathrm{NO}_{3}{ }^{-}$supplementation [30-32,48]. In addition to isokinetic torque, the effect of $\mathrm{NO}_{3}{ }^{-}$supplementation on different aspects of skeletal muscle contractile function is equivocal. Indeed, $\mathrm{NO}_{3}{ }^{-}$supplementation has been reported to increase force production at low stimulation frequencies in some $(\leq 20 \mathrm{~Hz})[22-24]$ but not all studies [25,26]. Although most studies have not observed an increase in maximal voluntary isometric contractile force after dietary $\mathrm{NO}_{3}{ }^{-}$supplementation $[19,22,23,25,26,28,29]$, improved weightlifting performance $[30-32,48,60]$ and concentric and eccentric contractile force during the back squat [61] have been reported after dietary $\mathrm{NO}_{3}{ }^{-}$supplementation. There is also evidence of an increased peak power output during a $30 \mathrm{~s}$ Wingate test after dietary $\mathrm{NO}_{3}{ }^{-}$supplementation [35-37]. Therefore, the possibility of $\mathrm{NO}_{3}{ }^{-}$supplementation improving skeletal muscle strength, power, and velocity cannot be excluded on the basis of the present meta-analysis, and further studies are warranted to provide greater clarity on the effects of $\mathrm{NO}_{3}{ }^{-}$ supplementation on skeletal muscle contractile function.

\section{Conclusions}

In conclusion, the current systematic review and meta-analysis indicates that acute dietary $\mathrm{NO}_{3}{ }^{-}$ ingestion is not likely to induce positive benefits to muscle peak torque production at a variety of angular velocities in the lower limbs, at least when assessed using isokinetic dynamometry. The lack of an effect of $\mathrm{NO}_{3}{ }^{-}$supplementation might be linked to $\mathrm{NO}$ bioavailability, which is modulated by factors such as dosing strategy, and participant health and training status, and sex. Given the paucity of literature, further research is required for a more complete understanding of the influence of $\mathrm{NO}_{3}{ }^{-}$ supplementation on different aspects of muscle strength.

Author Contributions: Á.L.-R., R.D., and P.J., conception and design of review; J.J.R.-Á., F.M.T., and P.J. performed the search of articles; J.J.R.-Á., F.M.T., and P.J. performed the quality analysis of the studies included in the meta-analysis; Á.L.-R. and R.D. extracted the data for performing the meta-analysis; Á.L.-R. carried out the meta-analysis statistical analysis and created figures and tables; Á.L.-R. and R.D. wrote the first draft of the manuscript; R.T. and S.J.B. edited and revised the manuscript. All authors have read and agreed to the published version of the manuscript.

Funding: This research received no external funding.

Conflicts of Interest: The authors declare no conflict of interest.

\section{References}

1. Stone, M.H.; Moir, G.; Glaister, M.; Sanders, R. How much strength is necessary? Phys. Ther. Sport 2002, 3, 88-96. [CrossRef]

2. Morrissey, M.C.; Harman, E.A.; Johnson, M.J. Resistance training modes: Specificity and effectiveness. Med. Sci. Sports Exerc. 1995, 27, 648-660. [CrossRef] [PubMed]

3. Bohannon, R.W. Considerations and practical options for measuring muscle strength: A narrative review. Biomed Res. Int. 2019. [CrossRef] [PubMed]

4. Gentil, P.; Del Vecchio, F.B.; Paoli, A.; Schoenfeld, B.J.; Bottaro, M. Isokinetic Dynamometry and 1RM Tests Produce Conflicting Results for Assessing Alterations in Muscle Strength. J. Hum. Kinet. 2017, 56, $19-27$. [CrossRef]

5. Paul, D.J.; Nassis, G.P. Testing strength and power in soccer players: The application of conventional and traditional methods of assessment. J. Strength Cond. Res. 2015, 29, 1748-1758. [CrossRef]

6. DeLang, M.D.; Rouissi, M.; Bragazzi, N.L.; Chamari, K.; Salamh, P.A. Soccer footedness and between-limbs muscle strength: Systematic review and meta-analysis. Int. J. Sports Physiol. Perform. 2019, 14, 551-562. [CrossRef] 
7. Perrin, D.H. Isokinetic Exercise and Assessment; Human Kinetics Publishers: Champaign, IL, USA, 1993; ISBN 0873224647.

8. Grgic, J.; Pickering, C. The effects of caffeine ingestion on isokinetic muscular strength: A meta-analysis. J. Sci. Med. Sport 2019, 22, 353-360. [CrossRef]

9. Kues, J.M.; Rothstein, J.M.; Lamb, R.L. Obtaining Reliable Measurements of Knee Extensor Torque Produced During Maximal Voluntary Contractions: An Experimental Investigation. Phys. Ther. 1992, 72, 492-501. [CrossRef]

10. Muñoz-Bermejo, L.; Pérez-Gómez, J.; Manzano, F.; Collado-Mateo, D.; Villafaina, S.; Adsuar, J.C. Reliability of isokinetic knee strength measurements in children: A systematic review and meta-analysis. PLoS ONE 2019, 14, e0226274. [CrossRef]

11. Abernethy, P.; Wilson, G.; Logan, P. Strength and Power Assessment: Issues, Controversies and Challenges. Sport Med. 1995, 19, 401-417. [CrossRef]

12. Gleeson, N.P.; Mercer, T.H. The utility of isokinetic dynamometry in the assessment of human muscle function. Sport Med. 1996, 21, 18-34. [CrossRef] [PubMed]

13. Kristensen, O.H.; Stenager, E.; Dalgas, U. Muscle Strength and Poststroke Hemiplegia: A Systematic Review of Muscle Strength Assessment and Muscle Strength Impairment. Arch. Phys. Med. Rehabil. 2017, 98, 368-380. [CrossRef] [PubMed]

14. Pontes, S.S.; de Carvalho, A.L.R.; Almeida, K.D.O.; Neves, M.P.; Ribeiro Schindler, I.F.S.; Alves, I.G.N.; Arcanjo, F.L.; Gomes-Neto, M. Effects of isokinetic muscle strengthening on muscle strength, mobility, and gait in post-stroke patients: A systematic review and meta-analysis. Clin. Rehabil. 2019, 33, 381-394. [CrossRef] [PubMed]

15. Garthe, I.; Maughan, R.J. International Journal of Sport Nutrition and Exercise Metabolism. J. Danc. Med. Sci. 2004, 8, 123.

16. Domínguez, R.; Maté-Muñoz, J.L.; Cuenca, E.; García-Fernández, P.; Mata-Ordoñez, F.; Lozano-Estevan, M.C.; Veiga-Herreros, P.; da Silva, S.F.; Garnacho-Castaño, M.V. Effects of beetroot juice supplementation on intermittent high-intensity exercise efforts. J. Int. Soc. Sports Nutr. 2018, 15, 1-12. [CrossRef]

17. Lundberg, J.O.; Weitzberg, E.; Gladwin, M.T. The nitrate-nitrite-nitric oxide pathway in physiology and therapeutics. Nat. Rev. Drug Discov. 2008, 7, 156-167. [CrossRef]

18. Jones, A.M. Dietary nitrate supplementation and exercise performance. Sport Med. 2014, 44, 35-45. [CrossRef]

19. Bailey, S.J.; Fulford, J.; Vanhatalo, A.; Winyard, P.G.; Blackwell, J.R.; DiMenna, F.J.; Wilkerson, D.P.; Benjamin, N.; Jones, A.M. Dietary nitrate supplementation enhances muscle contractile efficiency during knee-extensor exercise in humans. J. Appl. Physiol. 2010, 109, 135-148. [CrossRef]

20. Ferguson, S.K.; Hirai, D.M.; Copp, S.W.; Holdsworth, C.T.; Allen, J.D.; Jones, A.M.; Musch, T.I.; Poole, D.C. Impact of dietary nitrate supplementation via beetroot juice on exercising muscle vascular control in rats. J. Physiol. 2013, 591, 547-557. [CrossRef]

21. Hernández, A.; Schiffer, T.A.; Ivarsson, N.; Cheng, A.J.; Bruton, J.D.; Lundberg, J.O.; Weitzberg, E.; Westerblad, H. Dietary nitrate increases tetanic [Ca 2+] i and contractile force in mouse fast-twitch muscle. J. Physiol. 2012, 590, 3575-3583. [CrossRef]

22. Whitfield, J.; Gamu, D.; Heigenhauser, G.J.F.; Van Loon, L.J.C.; Spriet, L.L.; Tupling, A.R.; Holloway, G.P. Beetroot juice increases human muscle force without changing Ca2+-handling proteins. Med. Sci. Sports Exerc. 2017, 49, 2016-2024. [CrossRef] [PubMed]

23. Haider, G.; Folland, J.P. Nitrate supplementation enhances the contractile properties of human skeletal muscle. Med. Sci. Sports Exerc. 2014, 46, 2234-2243. [CrossRef] [PubMed]

24. Wickham, K.A.; McCarthy, D.G.; Pereira, J.M.; Cervone, D.T.; Verdijk, L.B.; van Loon, L.J.C.; Power, G.A.; Spriet, L.L. No effect of beetroot juice supplementation on exercise economy and performance in recreationally active females despite increased torque production. Physiol. Rep. 2019, 7, e13982. [CrossRef] [PubMed]

25. Hoon, M.W.; Fornusek, C.; Chapman, P.G.; Johnson, N.A. The effect of nitrate supplementation on muscle contraction in healthy adults. Eur. J. Sport Sci. 2015, 15, 712-719. [CrossRef]

26. Tillin, N.A.; Moudy, S.; Nourse, K.M.; Tyler, C.J. Nitrate Supplement Benefits Contractile Forces in Fatigued but Not Unfatigued Muscle. Med. Sci. Sports Exerc. 2018, 50, 2122-2131. [CrossRef]

27. Bender, D.; Townsend, J.R.; Vantrease, W.C.; Marshall, A.C.; Henry, R.N.; Heffington, S.H.; Johnson, K.D. Acute beetroot juice administration improves peak isometric force production in adolescent males. Appl. Physiol. Nutr. Metab. 2018, 43, 816-821. [CrossRef] 
28. Flanagan, S.D.; Looney, D.P.; Miller, M.J.S.; DuPont, W.H.; Pryor, L.; Creighton, B.C.; Sterczala, A.J.; Szivak, T.K.; Hooper, D.R.; Maresh, C.M.; et al. The Effects of Nitrate-Rich Supplementation on Neuromuscular Efficiency during Heavy Resistance Exercise. J. Am. Coll. Nutr. 2016, 35, 100-107. [CrossRef]

29. Fulford, J.; Winyard, P.G.; Vanhatalo, A.; Bailey, S.J.; Blackwell, J.R.; Jones, A.M. Influence of dietary nitrate supplementation on human skeletal muscle metabolism and force production during maximum voluntary contractions. Pflug. Arch. Eur. J. Physiol. 2013, 465, 517-528. [CrossRef]

30. Coggan, A.R.; Leibowitz, J.L.; Kadkhodayan, A.; Thomas, D.P.; Ramamurthy, S.; Spearie, C.A.; Waller, S.; Farmer, M.; Peterson, L.R. Effect of acute dietary nitrate intake on maximal knee extensor speed and power in healthy men and women. Nitric Oxide-Biol. Chem. 2015, 48, 16-21. [CrossRef]

31. Coggan, A.R.; Leibowitz, J.L.; Spearie, C.A.; Kadkhodayan, A.; Thomas, D.P.; Ramamurthy, S.; Mahmood, K.; Park, S.; Waller, S.; Farmer, M.; et al. Acute Dietary Nitrate Intake Improves Muscle Contractile Function in Patients with Heart Failure: A Double-Blind, Placebo-Controlled, Randomized Trial. Circ. Hear. Fail. 2015, 8, 914-920. [CrossRef]

32. Coggan, A.R.; Hoffman, R.L.; Gray, D.A.; Moorthi, R.N.; Thomas, D.P.; Leibowitz, J.L.; Thies, D.; Peterson, L.R. A Single Dose of Dietary Nitrate Increases Maximal Knee Extensor Angular Velocity and Power in Healthy Older Men and Women. J. Gerontol. Ser. A 2020, 75, 1154-1160. [CrossRef] [PubMed]

33. Henneman, E.; Somjen, G.; Carpenter, D.O. Excitability and inhibitibility of motoneurons of different sizes. J. Neurophysiol. 1965, 28, 599-620. [CrossRef] [PubMed]

34. Sargeant, A. Neuromuscular determinants of human performance. In Physiological Determinants of Exercise Tolerance in Humans; Whipp, B., Sargeant, A., Eds.; Portland Press: London, UK, 1999; pp. 13-28.

35. Domínguez, R.; Garnacho-Castaño, M.V.; Cuenca, E.; García-Fernández, P.; Muñoz-González, A.; de Jesús, F.; Lozano-Estevan, M.D.C.; Fernandes da Silva, S.; Veiga-Herreros, P.; Maté-Muñoz, J.L. Effects of beetroot juice supplementation on a 30-s high-intensity inertial cycle ergometer test. Nutrients 2017, 9, 1360. [CrossRef] [PubMed]

36. Cuenca, E.; Jodra, P.; Pérez-López, A.; González-Rodríguez, L.G.; da Silva, S.F.; Veiga-Herreros, P.; Domínguez, R. Effects of beetroot juice supplementation on performance and fatigue in a 30-s all-out sprint exercise: A randomized, double-blind cross-over study. Nutrients 2018, 10, 1222. [CrossRef]

37. Jodra, P.; Domínguez, R.; Sánchez-Oliver, A.J.; Veiga-Herreros, P.; Bailey, S.J. Effect of beetroot juice supplementation on mood, perceived exertion, and performance during a 30-second wingate test. Int. J. Sports Physiol. Perform. 2020, 15, 243-248. [CrossRef]

38. Rimer, E.G.; Peterson, L.R.; Coggan, A.R.; Martin, J.C. Increase in maximal cycling power with acute dietary nitrate supplementation. Int. J. Sports Physiol. Perform. 2016, 11, 715-720. [CrossRef]

39. Bailey, S.J.; Varnham, R.L.; DiMenna, F.J.; Breese, B.C.; Wylie, L.J.; Jones, A.M. Inorganic nitrate supplementation improves muscle oxygenation, $\mathrm{O} 2$ uptake kinetics, and exercise tolerance at high but not low pedal rates. J. Appl. Physiol. 2015, 118, 1396-1405. [CrossRef]

40. Kokkinoplitis, K.; Chester, N. The effect of beetroot juice on repeated sprint performance and muscle force production. J. Phys. Educ. Sport 2014, 14, 242. [CrossRef]

41. Shamseer, L.; Moher, D.; Clarke, M.; Ghersi, D.; Liberati, A.; Petticrew, M.; Shekelle, P.; Stewart, L.A.; Altman, D.G.; Booth, A.; et al. Preferred reporting items for systematic review and meta-analysis protocols (prisma-p) 2015: Elaboration and explanation. BMJ 2015, 349, 7647. [CrossRef]

42. Brown, P.; Brunnhuber, K.; Chalkidou, K.; Chalmers, I.; Clarke, M.; Fenton, M.; Forbes, C.; Glanville, J.; Hicks, N.J.; Moody, J.; et al. How to formulate research recommendations. Br. Med. J. 2006, 333, 804-806. [CrossRef]

43. Maher, C.G.; Sherrington, C.; Herbert, R.D.; Moseley, A.M.; Elkins, M. Reliability of the PEDro Scale for Rating Quality of Randomized Controlled Trials. Phys. Ther. 2003, 83, 713-721. [CrossRef] [PubMed]

44. Hedges, L.V. Distribution Theory for Glass's Estimator of Effect size and Related Estimators. J. Educ. Stat. 1981, 6, 107-128. [CrossRef]

45. Cohen, J. Statistical Power Analysis for the Behavioral Sciences, 2nd ed.; Hillsdale, N.J., Ed.; Lawrence Earlbaum Associates: New York, NY, USA, 1988; ISBN 0805802835.

46. Higgins, J.P.T.; Thomas, J.; Chandler, J.; Cumpston, M.; Li, T.; Page, M.J. Cochrane Handbook for Systematic Reviews of Interventions Version 6.0; Cochrane: London, UK, 2019.

47. Higgins, J.P.T.; Thompson, S.G.; Deeks, J.J.; Altman, D.G. Measuring inconsistency in meta-analyses. Br. Med. J. 2003, 327, 557-560. [CrossRef] [PubMed] 
48. Coggan, A.R.; Broadstreet, S.R.; Mikhalkova, D.; Bole, I.; Leibowitz, J.L.; Kadkhodayan, A.; Park, S.; Thomas, D.P.; Thies, D.; Peterson, L.R. Dietary nitrate-induced increases in human muscle power: High versus low responders. Physiol. Rep. 2018, 6, e13575. [CrossRef]

49. Wylie, L.J.; Kelly, J.; Bailey, S.J.; Blackwell, J.R.; Skiba, P.F.; Winyard, P.G.; Jeukendrup, A.E.; Vanhatalo, A.; Jones, A.M. Beetroot juice and exercise: Pharmacodynamic and dose-response relationships. J. Appl. Physiol. 2013, 115, 325-336. [CrossRef]

50. Kapil, V.; Milsom, A.B.; Okorie, M.; Maleki-Toyserkani, S.; Akram, F.; Rehman, F.; Arghandawi, S.; Pearl, V.; Benjamin, N.; Loukogeorgakis, S.; et al. Inorganic nitrate supplementation lowers blood pressure in humans: Role for nitrite-derived no. Hypertension 2010, 56, 274-281. [CrossRef]

51. Webb, A.J.; Patel, N.; Loukogeorgakis, S.; Okorie, M.; Aboud, Z.; Misra, S.; Rashid, R.; Miall, P.; Deanfield, J.; Benjamin, N.; et al. Acute blood pressure lowering, vasoprotective, and antiplatelet properties of dietary nitrate via bioconversion to nitrite. Hypertension 2008, 51, 784-790. [CrossRef]

52. Jo, E.; Fischer, M.; Auslander, A.T.; Beigarten, A.; Daggy, B.; Hansen, K.; Kessler, L.; Osmond, A.; Wang, H.; Wes, R. The effects of multi-day vs. Single pre-exercise nitrate supplement dosing on simulated cycling time trial performance and skeletal muscle oxygenation. J. Strength Cond. Res. 2019, 33, 217-224. [CrossRef]

53. Vanhatalo, A.; Bailey, S.J.; Blackwell, J.R.; DiMenna, F.J.; Pavey, T.G.; Wilkerson, D.P.; Benjamin, N.; Winyard, P.G.; Jones, A.M. Acute and chronic effects of dietary nitrate supplementation on blood pressure and the physiological responses to moderate-intensity and incremental exercise. Am. J. Physiol.-Regul. Integr. Comp. Physiol. 2010, 299, R1121-R1131. [CrossRef]

54. Nyakayiru, J.; van Loon, L.J.C.; Verdijk, L.B. Could intramuscular storage of dietary nitrate contribute to its ergogenic effect? A mini-review. Free Radic. Biol. Med. 2020, 152, 295-300. [CrossRef]

55. Van De Walle, G.P.; Vukovich, M.D. The effect of nitrate supplementation on exercise tolerance and performance: A systematic review and meta-analysis. J. Strength Cond. Res. 2018, 32, 1796-1808. [CrossRef] [PubMed]

56. Taddei, S.; Virdis, A.; Ghiadoni, L.; Salvetti, G.; Bernini, G.; Magagna, A.; Salvetti, A. Age-related reduction of NO availability and oxidative stress in humans. Hypertension 2001, 38, 274-279. [CrossRef] [PubMed]

57. Ivy, J.L. Inorganic Nitrate Supplementation for Cardiovascular Health. Methodist Debakey Cardiovasc. J. 2019, 15, 200-206. [CrossRef] [PubMed]

58. Katz, S.D.; Khan, T.; Zeballos, G.A.; Mathew, L.; Potharlanka, P.; Knecht, M.; Whelan, J. Decreased activity of the L-arginine-nitric oxide metabolic pathway in patients with congestive heart failure. Circulation 1999, 99, 2113-2117. [CrossRef]

59. Lauer, T.; Preik, M.; Rassaf, T.; Strauer, B.E.; Deussen, A.; Feelisch, M.; Kelm, M. Plasma nitrite rather than nitrate reflects regional endothelial nitric oxide synthase activity but lacks intrinsic vasodilator action. Proc. Natl. Acad. Sci. USA 2001, 98, 12814-12819. [CrossRef]

60. San Juan, A.F.; Dominguez, R.; Lago-Rodríguez, Á.; Montoya, J.J.; Tan, R.; Bailey, S.J. Effects of dietary nitrate supplementation on weightlifting exercise performance in healthy adults: A systematic review. Nutrients 2020, 12, 2227. [CrossRef]

61. Rodríguez-Fernández, A.; Castillo, D.; Raya-González, J.; Domínguez, R.; Bailey, S.J. Beetroot juice supplementation increases concentric and eccentric muscle power output. Original investigation. J. Sci. Med. Sport 2020. [CrossRef]

(C) 2020 by the authors. Licensee MDPI, Basel, Switzerland. This article is an open access article distributed under the terms and conditions of the Creative Commons Attribution (CC BY) license (http://creativecommons.org/licenses/by/4.0/). 